\title{
Stimulation of cellular proliferation by hepatitis B virus $\mathrm{X}$ protein
}

\author{
Charles R. Madden and Betty L. Slagle* \\ Department of Molecular Virology and Microbiology, \\ Baylor College of Medicine, Houston, TX 77030, USA
}

\begin{abstract}
Chronic infection with the hepatitis B virus (HBV) is a known risk factor in the development of human hepatocellular carcinoma (HCC). The HBV-encoded X protein, HBx, has been investigated for properties that may explain its cancer cofactor role in transgenic mouse lines. We discuss here recent data showing that $\mathrm{HBx}$ is able to induce hepatocellular proliferation in vitro and in vivo. This property of $\mathrm{HBx}$ is predicted to sensitize hepatocytes to other HCC cofactors, including exposure to carcinogens and to other hepatitis viruses. Cellular proliferation is intimately linked to the mechanism(s) by which most tumor-associated viruses transform virus-infected cells. The HBx alteration of the cell cycle provides an additional mechanism by which chronic HBV infection may contribute to HCC.
\end{abstract}

\section{Introduction}

At present, chronic viral infections are linked etiologically with $15 \%$ of all human cancers (reviewed in $[31,49]$ ). One such association involves the link between chronic hepatitis B virus (HBV) infection and the development of human hepatocellular carcinoma (HCC) [1]. There are an estimated 300 million chronically infected people worldwide, and HBVassociated HCC is one of the most common cancers in humans [34]. Because liver cancer arises in only a subset of infected patients, it is important to identify early markers of viral infection that can accurately predict those patients at risk for cancer.

* Address for correspondence: Department of Molecular Virology and Microbiology, Mailstop BCM-385, One Baylor Plaza, Baylor College of Medicine, Houston, TX 77030-3411, USA. Tel.: +1 713 798 3006; Fax: +1 713798 5075; E-mail: bslagle@bcm.tmc.edu.

\section{HBV and liver cancer}

The mechanism(s) by which HBV contributes to HCC formation is complex. Cycles of immunemediated cell death and regeneration are central to the pathogenesis of chronic viral infection (reviewed in [11]). The release of oxidants from resident phagocytes can damage liver DNA [19], and the compensatory cell proliferation that follows cell death increases the opportunity for cells to incur mutations necessary for tumor development (reviewed in [11]). During the decades-long chronic infection, portions of the viral genome integrate randomly into host cell DNA. While on rare occasions, this may lead to the direct disruption of a growth regulatory gene (reviewed in [38]), more commonly it leads to chromosomal rearrangements that include the loss of tumor suppressor genes (reviewed in [36]).

Less is known about the contribution(s) of virus-cell interactions, which are thought to evolve for the benefit of virus replication. Such interactions are particularly critical for small viruses like HBV, which has a limited genome size and replicates in resting hepatocytes. Many indirect-acting human tumor viruses encode viral oncoproteins that are essential for viral replication and cell transformation (reviewed in [7]). Although HBV does not appear to encode a direct acting oncogene, the 17-kDa HBx regulatory protein possesses several properties consistent with a role in transformation. Indeed, HBx has a cancer cofactor role in several transgenic mouse lines (Table 1).

\section{The $\mathrm{HBV}$ regulatory protein, $\mathrm{HBx}$}

HBx is a broadly acting transcriptional transactivator (reviewed in [6]) that is required for virus replication in vivo $[9,48]$. HBx can activate core gene expression in vivo [33], but additional functions of HBx important to the virus life cycle are not yet defined. In cell culture, HBx is reported to possess AMP kinase activity [14], to activate signaling pathways in the cell $[4,12,30]$, and 
Table 1

$\mathrm{HBx}$ is a cofactor in transgenic mice

\begin{tabular}{|c|c|c|c|c|}
\hline Regulatory region $^{\mathrm{a}}$ & Mouse strain & Pathology & Other observations & Role of HBx (Ref.) \\
\hline$\alpha$-1-anti-trypsin & Outbred (CD-1) & None & & None [27] \\
\hline HBV promoter & Outbred (CD-1) & $\mathrm{HCC}^{\mathrm{b}}(100 \%)$ & $10 \%$ spontaneous $\mathrm{HCC}$ & Cofactor [22] \\
\hline MUP & C57BL6 / x SJL & None & & None [18] \\
\hline$\alpha$-1-anti-trypsin & Outbred (ICR) & None & HCC with DEN & Cofactor [37] \\
\hline WHV promoter & Outbred (CD-1) & None & HCC with DEN & Cofactor [13] \\
\hline HBV promoter & C57B1/6 /DBA2 & None & HCC with activated $m y c$ & Cofactor [43] \\
\hline Anti-thrombin III & C57B1/6 /DBA2 & None & $\mathrm{HCC}$ with activated $m y c$ & Cofactor [43] \\
\hline
\end{tabular}

to inhibit the ability of cells to repair damaged DNA [2, 17,20,32]. The mechanism for the latter observation is unclear, and could be either direct (through proteinprotein interactions) or indirect.

How HBx acts as a cofactor in transgenic mice is not known. HBx inhibition of damaged DNA repair suggests one possible pathway, and would be particularly important in geographical locations in which HBx expression coincides with exposure to environmental carcinogens $[8,42]$. In cell culture, $\mathrm{HBx}$ sensitizes cells to carcinogen-induced mutations [39], and it is predicted that HBx will similarly cause an accumulation of DNA mutations in vivo. A double transgenic mouse model has been developed to answer this question [29]. Although HBx expression in the absence of exogenous DNA damage does not alter the in vivo DNA mutation frequency [29], carcinogen experiments now in progress should reveal whether HBx inhibits DNA repair in vivo (C. Madden and B. Slagle, unpublished). A second mechanism to explain the HBx cofactor role in transgenic mice centers on the demonstration that $\mathrm{HBx}$ can activate the Ras-Raf-Map Kinase signaling pathway in cell culture $[4,12,30]$. This property of $\mathrm{HBx}$ in vitro has led to the suggestion that $\mathrm{HBx}$ may act as a tumor promoter in vivo by stimulating hepatocellular growth [4].

\section{Induction of cellular proliferation by $\mathrm{HBx}$}

The induction of cell proliferation is intimately linked to the mechanism by which most tumorassociated viruses transform virus-infected cells. Several different tumor viruses (SV40, HPV-16, EBV) encode non-structural proteins that are able to stimulate resting cells to enter $S$ phase, in a strategy that provides a cellular environment favorable for viral DNA replication. The ability of these viruses to usurp cell cycle control appears related to their ability to cause cancer.
Recent studies clearly demonstrate that $\mathrm{HBx}$ can stimulate the proliferation of cells grown in culture. Upon release from quiescence induced by low serum concentrations, Chang liver epithelial cells expressing HBx move through the cell cycle (from Go to $\mathrm{S}$ phase, and into DNA synthesis) at an accelerated pace compared to control cells similarly released from that block $[3,4,39]$. Similarly, dexamethasone-induced HBx expression is sufficient to overcome a seruminduced Go block in NIH 3 T3 cells [24]. These studies establish that HBx may act as a mitogen to stimulate cell cycle progression in quiescent cells in vitro. It is likely that HBx-induced proliferation is under-reported, as the very nature of actively dividing cells in culture would diminish the ability to measure the proliferative effect of HBx.

The effect of $\mathrm{HBx}$ on hepatocyte proliferation in vivo is less clear. Most HBx transgenic mice do not develop tumors, indicating the need for additional cooperating events (Table 1). Analysis of HBx transgenic mice that are susceptible to spontaneous HCC [22] revealed an $\mathrm{HBx}$-associated increase in hepatocellular proliferation [25], while other HBx mice that do not develop HCCs lack an $\mathrm{HBx}$-associated proliferation [43, 44]. Our studies of transgenic mice in which a cofactor role for $\mathrm{HBx}$ has been established [27,37] revealed that livers from HBx (vs. nontransgenic) mice contained significantly more proliferating hepatocytes (Table 2 ; C. Madden, unpublished). These results indicate that $\mathrm{HBx}$ is able to induce hepatocellular proliferation under certain conditions in vivo. Interestingly, this property is conserved among at least three subtypes of $\mathrm{HBx}$, which differ by over $10 \%$ in the sequence identity (Table 2) [21].

A delicate balance between cellular proliferation and apoptosis is required for normal liver homeostasis. Since HBx is able to induce hepatocellular proliferation (Table 1), there must be a compensatory effect on apoptosis. Indeed, several studies have demon- 
Table 2

HBx effects on cellular proliferation

\begin{tabular}{|c|c|c|c|}
\hline X Subtype ${ }^{\mathrm{a}}$ & Regulatory region $^{\mathrm{b}}$ & Cell type & Effect of HBx expression (ref.) ${ }^{c}$ \\
\hline ayw & CMV & Chang liver epithelial & Increased entry into cell cycle $[3,4]$ \\
\hline $\mathrm{adr}$ & MMTV & Chang liver epithelial & Increased cell proliferation [24] \\
\hline ayw & AP2 & Chang liver epithelial & Increased entry into cell cycle [39] \\
\hline $\mathrm{adr}$ & $\mathrm{HBV}$ & Murine hepatocyte & Increased proliferation and apoptosis [25] \\
\hline $\operatorname{adw} 2$ & AAT & Murine hepatocyte & Increased proliferation $^{\mathrm{d}}$ \\
\hline \multicolumn{4}{|c|}{$\begin{array}{l}{ }^{\mathrm{a} X} \text { gene derived from different subtypes of } \mathrm{HBV} \text {, as listed. } \\
\text { b Regulatory region driving expression of } \mathrm{HBx} \text { : CMV, Cytomegalovirus promoter; MMTV, Mouse Mam- } \\
\text { mary Tumor Virus LTR; AP2, promoter responsive to AP2 transcription factor; HBV, native X promoter; } \\
\text { AAT, human } \alpha \text {-1-anti-trypsin promoter. } \\
{ }^{\mathrm{c}} \text { Ref., reference. } \\
\text { d C. Madden, manuscript submitted. }\end{array}$} \\
\hline
\end{tabular}

strated that HBx sensitizes cells to apoptosis in cell culture, although the mechanism by which $\mathrm{HBx}$ acts is unknown $[5,10,23,40]$. While $\mathrm{HBx}$ is reported to bind $553[15,46]$, to inhibit 533 sequence-specific DNA binding [47], and to inhibit p53 transactivation activity $[26,45,47]$, other studies have failed to support the idea that a p53 pathway is utilized in $\mathrm{HBx}$-mediated effects on apoptosis or proliferation [16,41]. Using the inducible Cre/loxP expression system, HBx detection preceded apoptosis by at least one day [35], a result in agreement with the need for additional cooperating events. Consistent with that observation, the HBxassociated increase in apoptosis in vivo was not limited to those cells expressing detectable HBx [25].

Together, these results reveal that $\mathrm{HBx}$ does sensitize cells to apoptosis in some experimental systems. Although the biologic significance of this remains unclear, an imbalance between cell death and regeneration in vivo may contribute significantly to viral pathogenesis over time.

\section{Implications of HBx-induced proliferation}

It can be presumed, by analogy with known tumor viruses, that the ability of HBx to induce cell proliferation somehow benefits viral replication. In other tumor virus systems, the binding to and inactivation of cellular genes involved in negative growth regulation, e.g., tumor suppressor genes, is critical for virus-induced cellular proliferation (reviewed in [28]). Data showing that HBx either stabilizes p53 or promotes its degradation, as has been shown for other tumor virus-encoded proteins, would provide much support for the hypothesis that HBx acts through a p53 pathway. The lack of a cell culture system for HBV severely limits studies designed to understand the contribution of HBx-induced proliferation to virus replication.
The observation that HBx can induce hepatocellular proliferation in the absence of an immune response (Table 2) is significant. The immune-mediated induction of hepatocellular proliferation during chronic viral infection is well established (reviewed in [11]). Continuous cycles of cell death and compensatory regeneration are considered central to the mechanism(s) by which chronic hepatitis viral infections lead eventually to the development of liver cancer. The virus-induced proliferation, regardless of the molecular mechanism, may set the stage for the accumulation of genetic mutations that result in cancer.

In the woodchuck hepatitis B virus model, expression of the homologous WHx protein is found only in cells that are permissive for viral replication [13]. A similar expression pattern for $\mathrm{HBx}$ would predict its expression during the decades of chronic infection, concomitant with exposure to environmental carcinogens in certain geographical regions $[8,42]$. Therefore, HBx-induced cellular proliferation of cells containing unrepaired DNA lesions would lead to fixation of those lesions into DNA mutations. This scenario could explain, in part, the synergy between chronic HBV infection and other HCC cofactors such as environmental carcinogens.

The above hypothesis can be tested experimentally using a new HBx transgenic mouse model that additionally contains a transgene that permits measurement of in vivo DNA mutation frequency. In those mice, HBx expression per se does not lead to liver pathology nor does it influence the accumulation of spontaneous DNA mutations [29]. However, a 3-fold increase in hepatocellular proliferation in HBx (vs. nontransgenic) livers could explain the increased susceptibility of those mice to hepatocarcinogens [13,37]. In this scenario, HBx might act by inducing the proliferation of cells containing unrepaired DNA lesions, thereby providing a growth advantage for the selection of a mutated cell. 


\section{Conclusion}

The cooperation between chronic HBV infection and other HCC cofactors in the etiology of HCC has been established. We review here data showing that $\mathrm{HBx}$ is able to induce hepatocellular proliferation in vivo, a property that presumably benefits some aspect of the virus life cycle. We propose that the ability of $\mathrm{HBx}$ to induce cellular proliferation may contribute to viral pathogenesis during the decades of chronic infection. The untimely proliferation of cells containing damaged DNA may lead to an increase in DNA mutations. In addition, $\mathrm{HBx}$-induced proliferation may sensitize cells to additional cofactors, such as chronic hepatitis $\mathrm{C}$ virus and/or dietary factors. Understanding the underlying mechanism of HBx-induced hepatocellular proliferation may reveal a molecular marker by which early HCCs can be identified, and lead to the identification of novel targets for intervention and treatment.

\section{Acknowledgements}

Some work cited in this review was supported by NIH research grant CA54557 (BLS). CRM was supported by research training grant T32DK07664.

\section{References}

[1] R.P. Beasley, L.Y. Hwang, C.C. Lin and C.S. Chien, Hepatocellular carcinoma and hepatitis B virus. A prospective study of 22707 men in Taiwan, Lancet 2 (1981), 1129-1133.

[2] S.A. Becker, T.H. Lee, J.S. Butel and B.L. Slagle, Hepatitis B virus $\mathrm{X}$ protein interferes with cellular DNA repair, J. Virol. 72 (1998), 266-272.

[3] J. Benn and R.J. Schneider, Hepatitis B virus HBx protein activates Ras-GTP complex formation and establishes a Ras, Raf, MAP kinase signaling cascade, Proc. Natl. Acad. Sci. 91 (1984), 10350-10354.

[4] J. Benn and R.J. Schneider, Hepatitis B virus HBx protein deregulates cell cycle checkpoint controls, Proc. Natl. Acad. Sci. 92 (1995), 11215-11219.

[5] F. Bergametti, S. Prigent, B. Luber, A. Benoit, P. Tiollais, A. Sarasin and C. Transy, The proapoptotic effect of hepatitis B virus $\mathrm{HBx}$ protein correlates with its transactivation activity in stably transfected cell lines, Oncogene 18 (1999), 2860-2871.

[6] M.A. Buendia, Mammalian hepatitis B viruses and primary liver cancer. [Review], Semin. Canc. Biol. 3 (1992), 309-320.

[7] J.S. Butel, Viral carcinogenesis: revelation of molecular mechanisms and etiology of human disease, Carcin. 21 (2000), $405-426$.

[8] C.J. Chen, M.W. Yu and Y.F. Liaw, Epidemiological characteristics and risk factors of hepatocellular carcinoma, J Gastroenterol Hepatol 12 (1997), S294-S308.
[9] H.-S. Chen, S. Kaneko, R. Girones, R.W. Anderson, W.E. Hornbuckle, B.C. Tennant, P.J. Cote, J.L. Gerin, R.H. Purcell and R.H. Miller, The woodchuck hepatitis virus $\mathrm{X}$ gene is important for establishment of virus infection in woodchucks, J. Virol. 67 (1993), 1218-1226.

[10] P. Chirillo, S. Pagano, G. Natoli, P.L. Puri, V.L. Burgio, C. Balsano and M. Levrero, The hepatitis B virus $\mathrm{X}$ gene induces p53-mediated programmed cell death, Proc. Natl. Acad. Sci. 94 (1997), 8162-8167.

[11] S. Christen, T.M. Hagen, M.K. Shigenaga and B.N. Ames, Chronic inflammation, mutation, and cancer, p. 35-88. in $\mathrm{Mi}$ crobes and Malignancy: infection as a cause of human cancers, J. Parsonet, ed., Oxford University Press, New York, New York, 1999.

[12] J.C. Cross, P. Wen and W.J. Rutter, Transactivation by hepatitis $\mathrm{B}$ virus $\mathrm{X}$ protein is promiscuous and dependent on mitogenactivated cellular serine/threonine kinases, Proc. Natl. Acad. Sci. 90 (1993), 8078-8082.

[13] M. Dandri, P. Schirmacher and C.E. Rogler, Woodchuck hepatitis virus $\mathrm{X}$ protein is present in chronically infected woodchuck liver and woodchuck hepatocellular carcinomas which are permissive for viral replication, J Virol. 70 (1996), 52465254.

[14] T.A.A. Dopheide and A.A. Azad, The hepatitis B virus X protein is a potent AMP kinase, J. Gen. Virol. 77 (1996), 173176.

[15] M.A. Feitelson, M. Zhu, L.X. Duan and W.T. London, Hepatitis $\mathrm{B} \times$ antigen and $\mathrm{p} 53$ are associated in vitro and in liver tissues from patients with primary hepatocellular carcinoma, Oncogene 8 (1993), 1109-1117.

[16] M.S. Greenblatt, M.A. Feitelson, M. Zhu, W.P. Bennett, J.A. Welsh, R. Jones, A. Borkowski and C.C. Harris, Integrity of p53 in hepatitis B X antigen-positive and -negative hepatocellular carcinomas, Canc. Res. 57 (1997), 426-432.

[17] I.J. Groisman, R. Koshy, F. Henkler, J.D. Groopman and M.A. Alaoui-Jamali, Downregulation of DNA excision repair by the hepatitis B virus-x protein occurs in p53-proficient and p53-deficient cells, Carcin. 20 (1999), 479-483.

[18] L.G. Guidotti, B. Matzke, C. Pasquinelli, J.M. Schoenberger, C.E. Rogler and F.V. Chisari, The hepatitis B virus (HBV) precore protein inhibits HBV replication in transgenic mice, J. Virol 70 (1996), 7056-7061.

[19] T.M. Hagen, S. Huang, J. Curnutte, P. Fowler, V. Martinez, C.M. Wehr, B.N. Ames and F.V. Chisari, Extensive oxidative DNA damage in hepatocytes of transgenic mice with chronic active hepatitis destined to develop hepatocellular carcinoma, Proc. Natl. Acad. Sci. 91 (1994), 12808-12812.

[20] L. Jia, X.W. Wang and C.C. Harris, Hepatitis B virus X protein inhibits nucleotide excision repair, Int. J. Cancer 80 (1999), 875-879.

[21] K. Kidd-Ljunggren, M. Oberg and A.H. Kidd, The hepatitis $\mathrm{B}$ virus $\mathrm{X}$ gene: analysis of functional domain variation and gene phylogeny using multiple sequences, J. Gen. Virol. 76 (1995), 2119-2130.

[22] C.-M. Kim, K. Koike, I. Saito, T. Miyamura and G. Jay, HBx gene of hepatitis B virus induces liver cancer in transgenic mice, Nature 351 (1991), 317-320.

[23] H. Kim, H. Lee and Y. Yun, X-gene product of hepatitis B virus induces apoptosis in liver cells, J Biol Chem. 273 (1998), 381-385.

[24] K. Koike, K. Moriya, H. Yotsuyanagi, S. Iino and K. Kurokawa, Induction of cell cycle progression by hepatitis B virus $\mathrm{HBx}$ gene expression in quiescent mouse fibroblasts, $J$. Clin. Invest. 94 (1994), 44-49. 
[25] K. Koike, K. Moriya, H. Yotsuyanagi, Y. Shintani, H. Fujie, T. Tsutsumi and S. Kimura, Compensatory apoptosis in preneoplastic liver of a transgenic mouse model for viral hepatocarcinogenesis, Canc. Lett. 134 (1998), 181-186.

[26] S.G. Lee and H.M. Rho, Transcriptional repression of the human p53 gene by hepatitis B viral X protein, Oncogene 19 (2000), 468-471.

[27] T.-H. Lee, M.F. Finegold, R.-F. Shen, J.L. DeMayo, S.L.C. Woo and J.S. Butel, Hepatitis B virus transactivator X protein is not tumorigenic in transgenic mice, $J$ Virol. 64 (1990), 59395947.

[28] A.J. Levine, The p53 protein and its interactions with the oncogene products of the small DNA tumor viruses, Virol. 177 (1990), 419-426.

[29] C.R. Madden, M.F. Finegold and B.L. Slagle, Expression of hepatitis B virus X protein does not alter the accumulation of spontaneous mutations in transgenic mice, J Virol. 74 (2000), 5266-5272.

[30] G. Natoli, M.L. Avantaggiati, P. Chirillo, P.L. Puri, A. Ianni, C. Balsano and M. Levrero, Ras- and Raf-dependent activation of c-Jun transcriptional activity by the hepatitis B virus transactivator pX, Oncogene 9 (1994), 2837-2843.

[31] D.M. Parkin, P. Pisani, N. Munoz and J. Ferlay, The global health burden of infection associated cancers, in: Cancer Surveys, R. Newton, V. Beral and R.A. Weiss, eds, Cold Spring Harbor Laboratory Press, New York, 1999, pp. 5-34.

[32] S. Prost, J.M. Ford, C. Taylor, J. Doig and D.J. Harrison, Hepatitis B x protein inhibits p53-dependent DNA repair in primary mouse hepatocytes, J Biol Chem. 273 (1998), 3332733332.

[33] K. Reifenberg, H. Wilts, J. Löhler, P. Nusser, R. Hanano, L.G. Guidotti, F.V. Chisari and H.J. Schlicht, The hepatitis B virus $\mathrm{X}$ protein transactivates viral core gene expression in vivo, $J$. Virol. 73 (1999), 10399-10405.

[34] W.S. Robinson, Hepatitis B virus and hepatocellular carcinoma, in: Microbes and Malignancy: Infection as a cause of human cancers, J. Parsonnet, ed., 1999, pp. 232-266.

[35] Y. Shintani, H. Yotsuyanagi, K. Moriya, H. Fujie, T. Tsutsumi, Y. Kanegae, S. Kimura, I. Saito and K. Koike, Induction of apoptosis after switch-on of the hepatitis B virus $\mathrm{X}$ gene mediated by the Cre/loxP recombination system, J. Gen. Virol. 80 (1999), 3257-3265.

[36] B.L. Slagle, S.A. Becker and J.S. Butel, Hepatitis viruses and liver cancer, in: Viruses and Cancer, (Vol. 51), A. Minson, J. Neil and M. McCrae, eds, University of Cambridge, Cambridge, England, 1994, pp. 149-171.

[37] B.L. Slagle, T.-H. Lee, D. Medina, M.J. Finegold and J.S. Butel, Increased sensitivity to the hepatocarcinogen diethylnitrosamine in transgenic mice carrying the hepatitis $\mathrm{B}$ virus $\mathrm{X}$ gene, Molec. Carc. 15 (1996), 261-269.
[38] B.L. Slagle, T.H. Lee and J.S. Butel, Hepatitis B virus and hepatocellular carcinoma. [Review], Prog Med Virol 39 (1992), $167-203$.

[39] S. Sohn, I. Jaitovitch-Groisman, N. Benlimame, J. Galipeau, G. Batist and M.A. Alaoui-Jamali, Retroviral expression of the hepatitis B virus $\mathrm{x}$ gene promotes liver cell susceptibility to carcinogen-induced site specific mutagenesis, Mut. Res. 460 (2000), 17-28.

[40] F. Su and R.J. Schneider, Hepatitis B virus HBx protein sensitizes cells to apoptotic killing by tumor necrosis factor $\alpha$, Proc. Natl. Acad. Sci. 94 (1997), 8744-8749.

[41] Q. Su, C.H. Schroder, G. Otto and P. Bannasch, Overexpression of p53 protein is not directly related to hepatitis $\mathrm{B} \times$ protein expression and is associated with neoplastic progression in hepatocellular carcinomas rather than hepatic preneoplasia, Mut. Res. 462 (2000), 365-380.

[42] Z. Sun, P. Lu, M.H. Gail, D. Pee, Q. Zhang, L. Ming, J. Wang, Y. Wu, G. Liu and Y. Zhu, Increased risk of hepatocellular carcinoma in male hepatitis B surface antigen carriers with chronic hepatitis who have detectable urinary aflatoxin metabolite M1, Hepatol 30 (1999), 379-383.

[43] O. Terradillos, O. Billet, C.A. Renard, R. Levy, T. Molina, P. Briand and M.A. Buendia, The hepatitis B virus X gene potentiates c-myc-induced liver oncogenesis in transgenic mice, Oncogene 14 (1997), 395-404.

[44] O. Terradillos, T. Pollicino, H. Lecoeur, M. Tripodi, M.L. Gougeon, P. Tiollais and M.A. Buendia, p53-independent apoptotic effects of the hepatitis B virus HBx protein in vivo and in vitro, Oncogene 17 (1998), 2115-2123.

[45] R. Truant, J. Antunovic, J. Greenblatt, C. Prives and J.A. Cromlish, Direct interaction of the hepatitis B virus HBx protein with p53 leads to inhibition by $\mathrm{HBx}$ of p53 response element-directed transactivation, J. Virol 69 (1995), 18511859.

[46] H. Ueda, S.J. Ullrich, J.D. Gangemi, C.A. Kappel, L. Ngo, M.A. Feitelson and G. Jay, Functional inactivation but not structural mutation of p53 causes liver cancer, Nat. Genet. 9 (1995), 41-47.

[47] X.W. Wang, K. Forrester, H. Yeh, M.A. Feitelson, J.R. Gu and C.C. Harris, Hepatitis B virus X protein inhibits $\mathrm{p} 53$ sequencespecific DNA binding, transcriptional activity, and association with transcription factor ERCC3, Proc. Natl. Acad. Sci. 91 (1994), 2230-2234.

[48] F. Zoulim, J. Saputelli and C. Seeger, Woodchuck hepatitis virus $\mathrm{X}$ protein is required for viral infection in vivo, $J$ Virol. 68 (1994), 2026-2030.

[49] H. zur Hausen, Viral Oncogenesis, in: Microbes and Malignancy: infection as a cause of human cancers, J. Parsonnet, ed., Oxford University Press, New York, NY, 1999, pp. 107130. 


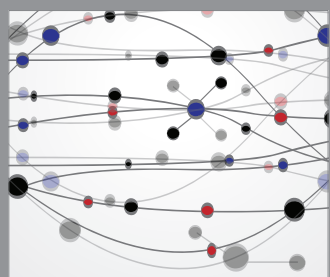

The Scientific World Journal
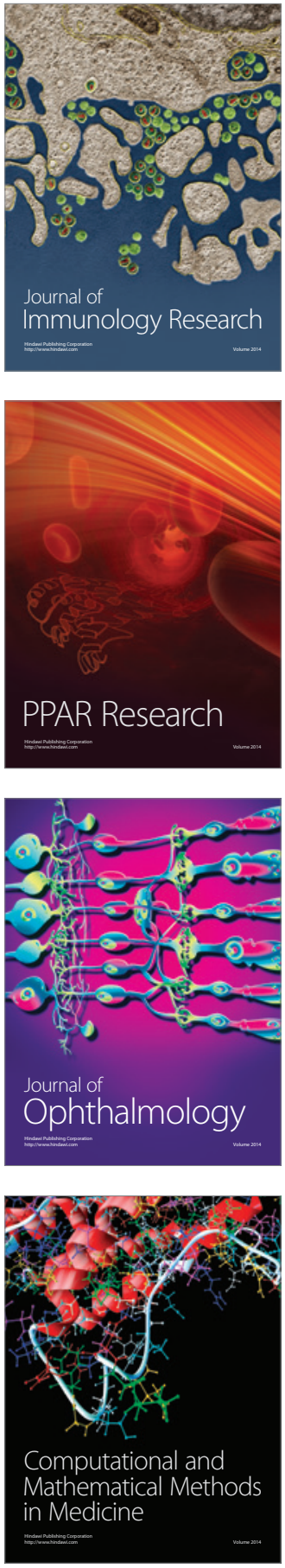

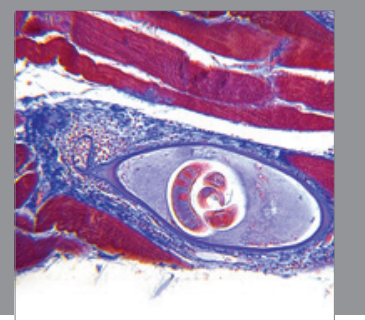

Gastroenterology

Research and Practice
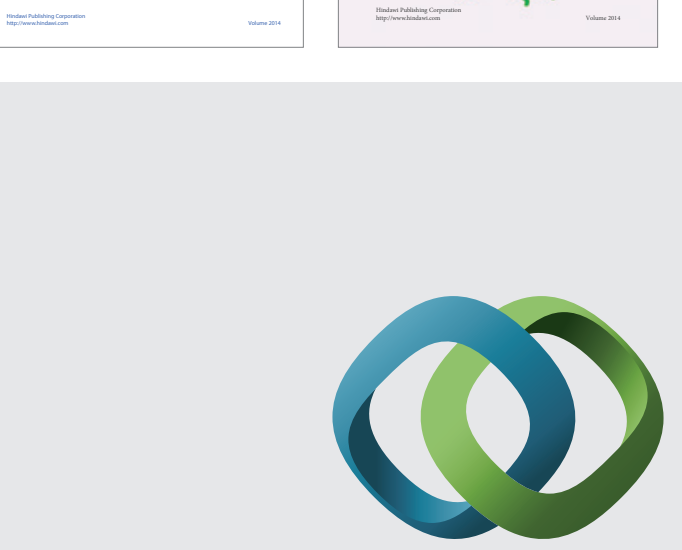

\section{Hindawi}

Submit your manuscripts at

http://www.hindawi.com
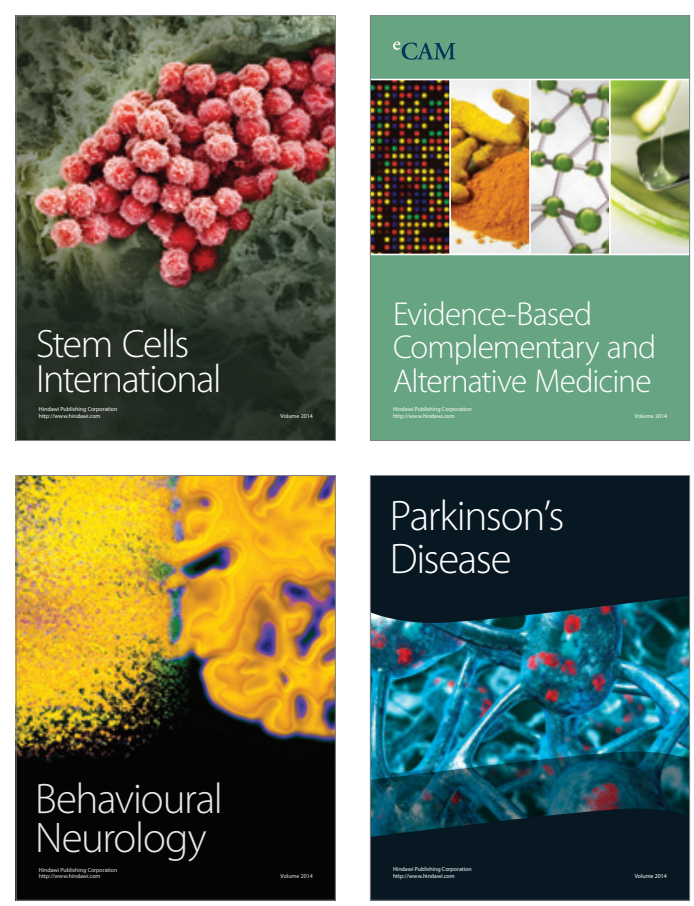

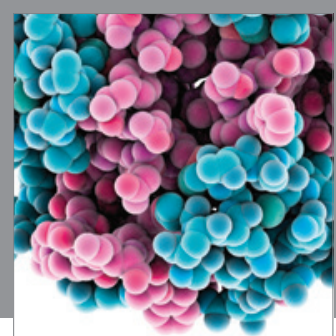

Journal of
Diabetes Research

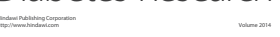

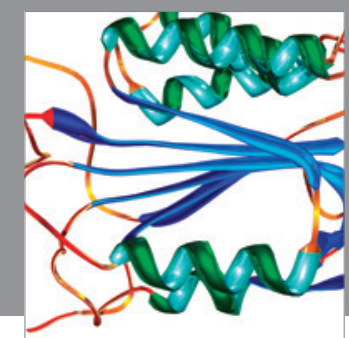

Disease Markers
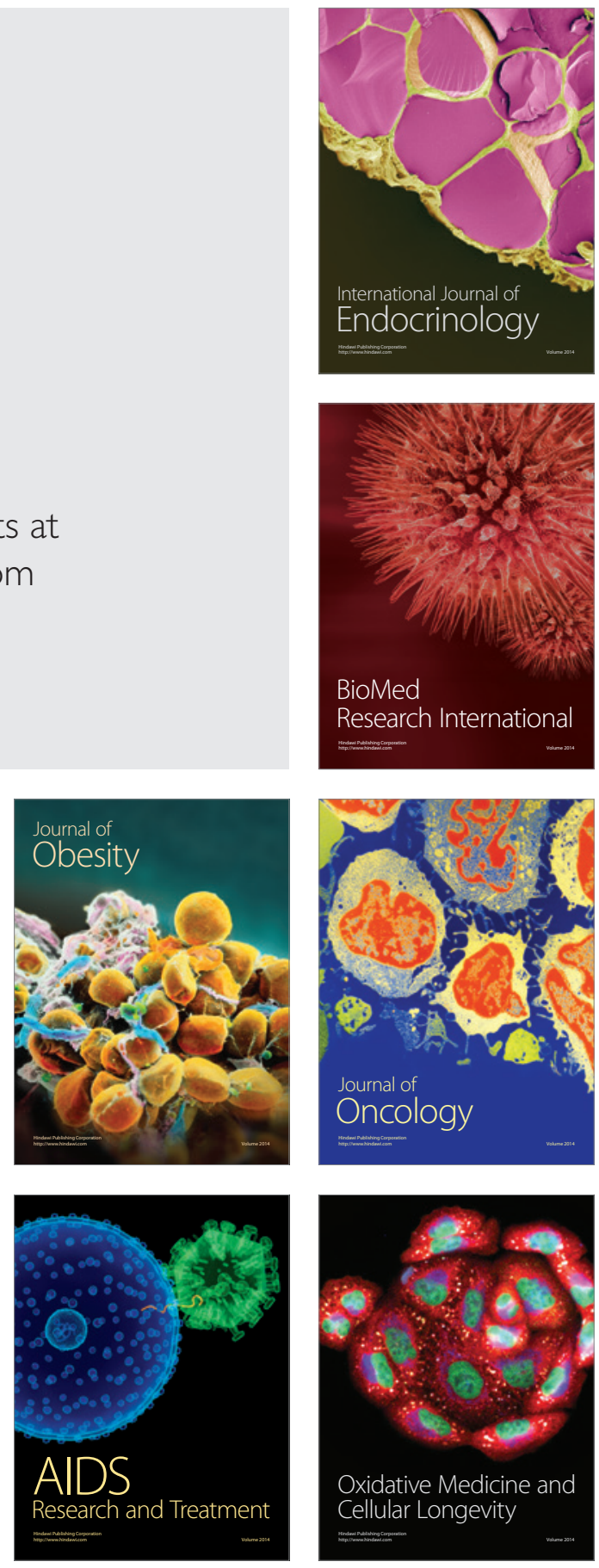